\title{
Layanan Air Bersih Melalui Sistem Distribusi Dalam Meningkatkan Layanan Masyarakat
}

\author{
Fajar Eryanto Septiawan', Enang Narlan Soetiman ${ }^{2}$ \\ 1,2 Universitas Langlangbuana, Indonesia. fajareryantos@gmail.com
}

\begin{abstract}
ABSTRAK
Air merupakan bagian penting dan tidak dapat terlepaskan dalam kehidupan manusia sehari-hari. Air memiliki arti penting bagi kesehatan manusia. Kesehatan masnusia dipengaruhi oleh asupan air yang diminum dan digunakan dalam kesehariannya. Menelaah fenomena masalah maka penelitian ini mengkaji layanan air bersih melalui sistem distribusi dalam meningkatkan layanan kepada masyarakat. Penelitian dilakukan melalui wawacara dan tinjauan lapangan pada Desa di Kota Bandung, tepatnya di Kelurahan Pasirluyu. Hasil penelitian ditemukan bahwa dengan tidak adanya toilet dirumah warga tersebut, warga melakukan kegiatan mandi, cuci kakus di sungai, sehingga tinja mencemari air dan diperparah dengan pencemaran dari limbah B3 yang biasanya diproduksi oleh pabrik-pabrik yang tidak bertanggung jawab mengolah limbah. Negara mengalami kerugian 56 triliun atau 2,3\% dari PDB akibat buruknya kualitas air minum dan sanitasi perumahan. Kualitas buruk tersebut dikarenakan dua hal penting yaitu rendahnya kesadaran masyarakat akan kepedulian terhadap ekosistem lingkungan dan alokasi anggaran yang rendah dari pemerintah baik pusat maupun daerah. Rendahnya tingkat pelayanan air memiliki dampak langsung terhadap kualitas kesehatan masyarakat yang serta merta menjadi buruk pula. Kualitas kesehatan yang buruk antara lain disebabkan oleh meminum air yang tidak murni dan layak minum sehingga akan berbahaya bagi tubuh dikarenakan tubuh akan melakukan filter sendiri terhadap zat-zat berbahaya yang terdapat dalam air dan dikonsumsi pada masyarakat pada umumnya. Setidaknya hasil penelian ini berdampak pada kebijakan pemerintah daerah dalam menilai layanan masyarakat, serta mendukung upaya perkembangan desa seperti desa wisata.
\end{abstract}

Kata Kunci: Air Bersih, Distribusi, Layanan Masyarakat.

\begin{abstract}
Water is an important and inseparable part of everyday human life. Water has an important meaning for human health. Human health is influenced by the intake of water they drink and use in their daily lives. Examining the phenomenon of the problem, this study examines clean water services through the distribution system in improving services to the community. The research was conducted through interviews and field reviews in villages in the city of Bandung, precisely in Pasirluyu Village. The results showed that in the absence of toilets in the residents' houses, the residents bathed, washed the latrines in the river so that the feces polluted the water and was exacerbated by pollution from B3 waste which is usually produced by factories that are not responsible for treating the waste. The country suffered a loss of 56 trillion or $2.3 \%$ of GDP due to poor quality of drinking water and housing sanitation. This poor quality is due to two important things, namely low public awareness of concern for environmental ecosystems and low budget allocations from both central and local governments. The low level of water services has a direct impact on the quality of public health, which in turn becomes worse. Poor health quality is caused, among others, by drinking water that is not pure and suitable for drinking so that it will be harmful to the body because the body will filter itself against harmful substances contained in water and consumed by the general public. At least the results of this study have an impact on local government policies in assessing community services, as well as supporting efforts to develop villages such as tourism villages.
\end{abstract}

Keywords: Clean Water, Distribution, Community Services. 


\section{PENDAHULUAN}

Air merupakan bagian penting dan tidak dapat terlepaskan dalam kehidupan manusia sehari-hari (Adisasmito, 2007). Air memiliki arti penting bagi kesehatan manusia. Kesehatan masnusia dipengaruhi oleh asupan air yang diminum dan digunakan dalam kesehariannya. Dalam kehidupan, manusia sangatlah membutuhkan air, karena dalam tubuh manusia setidaknya $80 \%$ merupakan komponen air (Sukartini \& Saleh, 2016). Seiring meningkatnya populasi manusia maka dapat dipastikan meningkat pula kebutuhan akan air terutama air bersih yang layak diminum dan dipergunakan untuk melakukan kegiatan sehari-hari seperti mandi, mencuci, dan kakus.

Manusia bersaing dengan alam dalam pemenuhan kebutuhan akan air. Hal tersebut mengharuskan manusia agar selalu menjaga kondisi lingkungan sehingga ketersediaan air dapat terjaga pula (Amalia \& Sugiri, 2014). Fenomena yang terjadi sekarang ini adalah di kala hujan sering terjadi banjir dimana-mana, namun seballiknya disaat kemarau kekeringan dan krisis air juga terjadi di berbagai wilayah yang sebenarnya memiliki potensi sumber daya air yang besar. Penyalahgunaan sumber daya air menghasilkan knsekuensi logis diantaranya adalah air menjadi langka dan menjadi suatu produk yang berharga mahal (Kusumawardani, 2011). Kelangkaan air bersih dan sanitasi merupakan suatu masalah yang tak kunjung usai dan harus dicarikan solusinya. Apabila masalah tersebut dapat teratasi maka ketersediaan air bersih dapat terjaga selamannya.

Beberapa tahun terakhir 100 ribu bayi tewas karena mengalami diare akut. Diare akut merupakan penyait mematikan nomor 2 setelah ISPA. Salah satu penyebab diare adalah adanya infeksi oleh bakteri ecoli dalam saluran pencernaan (Adisasmito, 2007). Mengenaskannya, pencemaran lingkungan sangat tinggi, $60 \%$ sungai sudah tercemar ecoli padahal sungai merupakan salah satu sumber air baku. Air sungai yang seharusnya menjadi sumber malah dicemari oleh berbagai macam polutan dan tentunya hal tersebut menyebabkan orang rentan terhadap penyakit (Cahyadi et al., 2013). Dari hari ke hari masalah semakin kompleks, akses buruk terhadap air bersih terjadi $20 \%$ di perkotaan dan $80 \%$ mengonsumsi air tak layak minum. Masalah sanitasi memperburuk problematika terkait air bersih sehungga masalah-masalah tersebut harus segeraditemukan solusi yang praktis namun tepat sasaran (Sukartini \& Saleh, 2016). Disinilah manajemen berperan dalam penyediaan, pendistribusian, dan penigkatan kualitas air yang dilakukan secara efektif dan efiseien dalam upaya meminimalisasi penggunaan biaya berlebih (Hijriani et al., 2016). Diharapkan dengan prinsip efektivitas dan efisiensi pemenuhan kebutuhan air bersih dapat tercapai sehingga warga dapat menikmati air bersih dengan harga terjangkau dan kualitas unggul. Dampak dari hal tersebut diharapkan dapat menigkatkan kualitas kesehatan dan hasil akhirnya adalah peningkatan kualitas hidup mansyarakat sehingga dapat tercipta SDM unggul yang sehat (Sukartini \& Saleh, 2016).

Manajemen sangat berperan dalam perencanaan, pengorganisasian, pelaksanaan serta kontrol dan evaluasi untuk memastikan bahwa distribusi air bersih berjalan sebagaimana mestinya (Kurnianingrum et al., 2019). Saat ini baru 29\% di Indonesia yang dapat mengakses air bersih lewat perpipaan. Pada tahun 2019 di tergetkan $60 \%$ dapat mengakses air bersih melalui system perpipaan hal itu sejalan dengan SDGs yang ingin dicapai pada tahun 2030 nanti. Kondisi eksisting yang terjadi sekarang ini kualitas air permukaan turun, hal tersebut mengarah pada kecurigaan terhadap air tanah berlebih oleh hotel dan mall bersekala besar (Mudrikah et al., 2014). Masalah itu lumrah terjadi di daerah perkotaan. Padahal menurut data kependudukan bahwa tingkat urbanisai dari tahun ke tahun semakin mengkat. Dengan semakin tingginya urbanisasi semakin banyak pula daerah kumuh padat penduduk yang tidak mempunyai akses terhadap air bersih dan sanitasi layak.

Taraf air minum dari waktu ke waktu semakin menghawatirkan salah satu penyebabnya adalah bertumpuknya masyarakat di suatu lokasi (Cahyadi et al., 2013). Penumpukan itu menyebabkan keubutuhan akan air pun semakin bertambah, sedangkan ketersediaan air begitubegitu saja. Kurang lebih 60-210 liter air perorang merupakan kebutuhan air harian perorangan. Terkait hal tersebut masalah air baku yang paling utama adalah layanan publik tentang air, regulasi, listrik, utang, dan kebocoran pipa distribusi. Pemerintah sudah menggelontorkan dana sebesar 275 triliun untuk mengatasi masalah air baku dan 273,7 triliun untuk masalah sanitasi namun masih dirasa belum cukup untuk menanggulangi masalah tersebut.

Sebagai pertimbangan bahwa pada tahun 2025 diperkirakan jumlah penduduk di Indonesia mencapai 321 juta jiwa (Tusianti, Ema; Prihatiningsih, Dyah Retno; Santosa, 2019). Tentu saa kebutuhan akan air bersih meningkat tajam. 
Maka dari itu perlu secepatnya dipersiapkan baik sarana maupun prasarana untuk pemenuhan kebutuhan air bersih. Untuk skala wilayah kecil, pemerintah memiliki program submersible pump yang telah di implementasikan di beberapa kelurahan khususnya di kota Bandung (Sukartini \& Saleh, 2016). Keberadaan submersible pump dapat dikatakan sebagai salah satu solusi alternatif pemenuhan kebutuhan air bersih di daerah padat penduduk. Berdasarkan survey awal, warga merasa cukup puas dengan adanya program pemerintah tersebut. Akses akan air bersih mudah di dapat dan kualitas sanitasi meningkat dibanding sebelumnya. Walau pun demikian masih perlu ditingkatkan dalam beberapa aspek diantanya aspek pelayanan yang meliputi ketersediaan, distribusi, dan kualitas air tersebut.

Menelaah fenomena penelitian maka penelitian ini fokus pada kajian layanan air bersih melalui sistem terdistribusi pada wilayah layanan daerah. Adapun studi kasus pada Kelurahan Pasirluyu di Kota Bandung

\section{KAJIAN PUSTAKA}

\section{Sistem Distribusi Air}

Sistem distribusi air bersih adalah pendistribusian atau pembagian air melalui sistem perpipaan dari bangunan pengolahan (reservoir) kedaerah pelayanan (Kalensun et al., 2016). Pipa merupakan komponen utama dalam jaringan perpipaan meliputi transmisi dan distribusi. Sistem distribusi air (Water Distribution Systems) berfungsi melayani masyarakat dan membantu daya ekonomi dengan mengalirkan air dari sumbersumber air kepada konsumen (Rivai et al., 2004). Suatu WDS terdiri dari tiga komponen utama, yaitu sumber air, pengolahan, dan jaringan distribusi. Sumber air dapat berupa waduk, sungai, atau sumur air tanah. Fasilitas pengolahan dapat berupa air disinfeksi (pemusnah kuman), air minum standar, kualitas air sebelum didistribusikan ke konsumen (Novita \& Marsono, 2019). Jaringan distribusi bertanggung jawab untuk memberikan air dari sumber atau fasilitas pengolahan kepada konsumen pada tekanan yang mencukupi dan terutama terdiri dari pipa, pompa, simpul (persimpangan), katup, fitting, dan tangki penyimpanan.

Sebuah WDS bisa menggunakan pompa mekanik untuk memasok air ke konsumen, tapi dengan hanya menggunakan pompa saja akan bermasalah karena diperlukan pompa yang dapat berfluktuasi terus-menerus untuk memenuhi kebutuhan konsumen yang sangat bervariasi
(Yusuf et al., 2019). Karena berbagai pola kebutuhan air, sebagian besar sistem distribusi perkotaan memanfaatkan pompa dengan meninggikan tangki penyimpanan. Tangki ini membantu terpenuhinya kebutuhan konsumen yang berfluktuasi, menampung kebutuhan pemadam kebakaran selama kondisi darurat, dan menstabilkan tekanan operasi. Biasanya, tangki digunakan selama jam-jam puncak penggunaan air dan diisi ulang selama masa permintaan rendah (Makawimbang, A. Feby, L. Tanudjaja, 2017).

Suatu sistem dapat dipertahankan operasionalnya dengan meningkatkan keamanan, redundansi, keandalan, dan ketahanan dari sistem tersebut (Mananoma et al., 2016). Keamanan sistem mencakup semua upaya untuk mencegah masuknya sesuatu ke dalam sistem, seperti pagar, penjaga, dan video. Keberadaan suatu WDS hanya dengan mengandalkan keamanan saja akan menjadi sulit dan tidak efisien karena memerlukan sejumlah tenaga kerja praktis yang ringan dan biaya untuk mempertahankan kesiagaan tinggi untuk mencegah peristiwa langka dan unik (Walangare et al., 2013).

\section{Layanan Masyarakat}

Pelayanan kepada masyarakat merupakan suatu bentuk interaksi antara penyedia layanan dan penerima layanan (Adisasmito, 2007). Dengan kata lain dalam hubungan pemerintahan terkandung makna adanya organisasi yang memerintah dan masyarakat yang diperintah (Karsidi, 2007). Birokrasi merupakan organisasi atau unit kerja publik yang berfungsi sebagai provider layanan. Konsep birokrasi yang banyak diterima sampai sekarang adalah teori yang dikembangkan oleh Max Weber yang mendefinisikan karakteristik suatu organisasi yang memaksimumkan stabilitas dan untuk mengendalikan anggota organisasi dalam rangka mencapai tujuan bersama (McDonald, 2011). Layanan yang dibutuhkan masyarakat adalah alat untuk mengakui, memenuhi dan melindungi hak asasi dan hak-hak yang diperoleh dalam konstelasi perjalanan hidup manusia seperti keadilan, keamanan, kepastian hukum, kemerdekaan, kebebasan memilih dan lain-lain (Anderson et al., 2000).

Lemahnya pelayanan publik dimungkinkan oleh beberapa sebab, di antaranya adalah pertama, kurangnya kesadaran terhadap tugas dan kewajiban yang menjadi tanggungjawabnya (Wahyudi, 2011). Akibatnya mereka bekerja dan melayani sekedarnya, padahal orang yang 
menunggu hasil kerjanya sudah gelisah. Akibat dari hal ini adalah tidak adanya disiplin kerja. Kedua, sistem, prosedur dan metode kerja yang tidak memadai sehingga mekanisme kerja tidak berjalan sebagaimana yang diharapkan (Rizkiana et al., 2008). Ketiga, pengorganisasian tugas pelayanan yang belum serasi, sehingga terjadi kesimpang siuran penanganan tugas, tumpang tindih (overlapping) atau tercecernya tugas tidak ada yang menangani. Keempat, pendapatan pegawai yang tidak mencukupi memenuhi kebutuhan hidup meskipun secara minimal (Hijriani et al., 2016). Akibatnya pegawai tidak tenang dalam bekerja, berusaha mencari tambahan pendapatan dalam jam kerja dengan cara antara lain "menjual" jasa pelayanan. Kelima, kemampuan pegawai yang tidak memadai untuk tugas yang dibebankan kepadanya. Akibatnya hasil pekerjaan tidak memenuhi standar yang telah ditetapkan. Keenam, tidak tersedianya sarana pelayanan yang memadai. Akibatnya, pekerjaan menjadi lamban dan waktu banyak hilang dan penyelesaian masalah terlambat (Rizkiana et al., 2008).

Agar pelayanan publik berjalan dengan baik maka diperlukan beberapa faktor pendukung, yaitu kesadaran, aturan, organisasi, pendapatan, kemampuan keterampilan, dan sarana pelayanan. Dengan demikian, pada hakikatnya, lemahnya pelayanan publik bermuara pada dua faktor utama, yaitu faktor manusia sebagai faktor utama, dan faktor sistem, karena untuk perbaikannya diperlukan perbaikan terhadap kedua unsur tersebut (Penelitian et al., 2006).

\section{METODOLOGI PENELITIAN}

Penelitian ini merupakan penelitian deskriptif dengan analisis yang dilakukan pada responden melalui wawancara dan observasi. Responden dalam penelitian adalah masyarakat yang menerima layanan air bersih di Kelurahan Pasirluyu Kota Bandung. Analisis lanjutan dilakukan dengan diskusi melalui FGD untuk menelaan dan menemukan solusi dari permasalahan terkait sistem distribusi pada layanan air bersih.

\section{HASIL DAN PEMBAHASAN \\ Analisis Situasi Objek Penelitian}

Kelurahan Pasirluyu Kecamatan Regol Kota

Bandung merupakan salah satu bagian di wilayah Kota Bandung dengan memiliki luas lahan sebesar 79 ha. Secara administratif Kelurahan Pasirluyu Kecamatan Regol Kota Bandung. Secara geografis Kelurahan Pasirluyu Kecamatan Regol
Kota Bandung memiliki bentuk wilayah datar/berombak sebesar 98,5\% dari total keseluruhan luas wilayah. Ditinjau dari sudut ketinggian tanah, Kelurahan Pasirluyu Kecamatan Regol Kota Bandung berada pada ketinggian 755 $\mathrm{m}$ diatas permukaan air laut.

Letak Kecamatan Regol yang berada di tengah-tengah Kota Bandung membuat Kecamatan Regol memiliki udara yang panas. Daerah ini jarang memiliki pohon karena digunakan untuk permukiman dan jalan raya. Wilayah Kecamatan Regol yang terletak berada tidak jauh dari pusat kota memiliki daya tarik tersendiri untuk para wisatawan yang dating, baik dari luar kota Bandung maupun dari dalam kota Bandung itu sendiri.

Kelurahan Pasirluyu terdiri dari 9 Rukun Warga (RW) dan 63 Rukun Tetangga (RT). Jumlah penduduk pada tahun 2015 sebanyak 17.296 jiwa, terdiri dari 8.783 laki-laki dan 8.513 perempuan. Kelurahan Pasirluyu memiliki jumlah penduduk tertinggi dibanding kelurahan lain di Kecamatan Regol. Jumlah penduduk Kelurahan Paisrluyu berdasarkan golongan agama pada tahun 2014 adalah sebagai berikut: agama Islam sebanyak 13.969 orang, Protestan sebanyak 519 orang, Katolik sebanyak 422 orang, Hindu sebanyak 3 orang, dan agama Budha sebanyak 22 orang. Jumlah sarana peribadatan adalah sebagai berikut: masjid sebanyak 10 unit, langar sebanyak 4 unit.

\section{Layanan Air Bersih Pada Objek Penelitian}

Kelurahan Pasirluyu secara geografis sangat erat kaitannya dengan eksistensi sungai cikapundung. Seharusnya dengan keunggulan letak geografis tersebut, ketersediaan air melimpah karena sangat dekat dengan sumbernya yaitu sungai cikapundung. Apa daya ternyata kualitas air di sungai cikapundung sangat tidak layak untuk digunakan sehari-hari apa lagi untuk diminum. Sungai cikapundung sudah tercemar berbagai macam poutan baik itu organic maupun anorganik. Warga kelurahan pasirluyu pada umumnya memanfaatkan sumur-sumur yang sudah ada dari jaman dahulu sebagai sumber airnya. Kebradaan sumur itu belum dapat memenuhi kebutuhan air warga secara optimal, karena debit airnya belum maksimal apabila dibandingkan dengan kebutuhan warga. Secara kualitas, air dari sumur tersebut belum pernah diuji oleh laboratorium mengenai kelayakan untuk diminum dan tidak mengandung zat berbahaya.

Pemerintah kota melalui kelurahan dan RW setempat mengimplementasikan program 
pembuatan sumur submersible pump sebagai salah satu upaya pemenuhan kebutuhan air bersih untuk warga RW 01 kelurahan pasirluyu. Akses mendapatkan air bersih semakin mudah karena air dari sumber tersebut disalurkan melalui jaringan pipa yang juga disediakan oleh pemerintah. Warga yang berminat untuk dapat mengakses air dari sumber itu diberikan meteran di masing-masing rumah sebagai alat ukur yang sah untuk melihat pemakaian air bulanan. Walaupun bersifat bantuan dari pemerintah, namun untuk biaya operasional dibebankan kepada warga yang telah memiliki meteran air tersebut. Meteran air tersebut selalu diperiksa oleh petugas dari RW untuk mencatat angka penggunaan pada meter air. Warga diwajibkan membayar pemakaian air yang berdasarkan pencatatan meter air.

Solusi yang telah diimplementasikan masih memiliki beberapa kekurangan diantaranya adalah belum dilakukan uji laboratorium terkait kelayakan air dari sumber tersebut untuk dapat dikonsumsi sehari-hari oleh warga. Pencatatan meteran masih dailakukan secara manual. Belum dilakukan tera secara periodic terhadap meter air yang terpasang di masing-masing rumah warga. Hal substansif lainnya yaitu kualitas sanitasi warga masih belum disebut layak untuk dipergunakan sehari-hari, maka perlu dilakukan program edukasi yang terkait dengan kebersihan serta keklayakan sanitasi sehingga dapat tercipta kualitas kesehatan yang lebih baik dan mendorong terwujudnya kualitas hidup unggul.

Permasalahan prioritas yang dihadapi oleh masyarakat RW 01 Kelurahan Pasirluyu adalah

1. Kualitas air dari Submersible Pump yang belum diuji oleh laboratorium.

2. Pencatatan meter air masih konvensional. Sehingga rentan terjadi kesalahan.

3. Tidak dilakukannya tera berkala pada meter air, kemungkinan bisa terjadi eror.

\section{Sistem Distribusi Air Bersih}

Beberapa tahun terakhir 100 ribu bayi tewas karena mengalami diare akut. Diare akut merupakan penyait mematikan nomor 2 setelah ISPA. Salah satu penyebab diare adalah adanya infeksi oleh bakteri ecoli dalam saluran pencernaan. Mengenaskannya, pencemaran lingkungan sangat tinggi, 60\% sungai sudah tercemar ecoli padahal sungai merupakan salah satu sumber air baku. Air sungai yang seharusnya menjadi sumber malah dicemari oleh berbagai macam polutan dan tentunya hal tersebut menyebabkan orang rentan terhadap penyakit.
Dari hari ke hari masalah semakin kompleks, akses buruk terhadap air bersih terjadi $20 \%$ di perkotaan dan $80 \%$ mengonsumsi air tak layak minum. Masalah sanitasi memperburuk problematika terkait air bersih sehungga masalahmasalah tersebut harus segera ditemukan solusi yang praktis namun tepat sasaran. Disinilah manajemen berperan dalam penyediaan, pendistribusian, dan penigkatan kualitas air yang dilakukan secara efektif dan efiseien dalam upaya meminimalisasi penggunaan biaya berlebih. Diharapkan dengan prinsip efektivitas dan efisiensi pemenuhan kebutuhan air bersih dapat tercapai sehingga warga dapat menikmati air bersih dengan harga terjangkau dan kualitas unggul. Dampak dari hal tersebut diharapkan dapat menigkatkan kualitas kesehatan dan hasil akhirnya adalah penignkatan kualitas hidup mansyarakat sehingga dapat tercipta SDM unggul yang sehat.

Manajemen sangat berperan dalam perencanaan, pengorganisasian, pelaksanaan serta kontroldan evaluasi untuk memastikan bahwa distribusi air bersih berjalan sebagaimana mestinya. Saat ini baru 29\% di Indonesia yang dapat mengakses air bersih lewat perpipaan. Pada tahun 2019 di tergetkan 60\% dapat mengakses air bersih melalui system perpipaan hal itu sejalan dengan SDGs yang ingin dicapai pada tahun 2030 nanti. Konsidi eksisting yang terjadi sekarang ini kualitas air permukaan turun, hal tersebut mengarah pada kecurigaan terhadap air tanah berlebih oleh hotel dan mall bersekala besar. Masalah itu lumrah terjadi di daerah perkotaan. Padahal menurut data kependudukan bahwa tingkat urbanisai dari tahun ke tahun semakin mengkat. Dengan semakin tingginya urbanisasi semakin banyak pula daerah kumuh padat penduduk yang tidak mempunyai akses terhadap air bersih dan sanitasi layak.

Taraf air minum dari waktu ke waktu semakin menghawatirkan salah satu penyebabnya adalah bertumpuknya masyarakat di suatu lokasi. Penumpukan itu menyebabkan keubutuhan akan air pun semakin bertambah, sedangkan ketersediaan air begitu-begitu saja. Kurang lebih 60-210 liter air perorang merupakan kebutuhan air harian perorangan. Terkait hal tersebut masalah air baku yang paling utama adalah layanan public tentang air, regulasi, listrik, utang, dan kebocoran pipa distribusi. Pemerintah sudah menggelontorkan dana sebesar 275 triliun untuk mengatasi masalah air baku dan 273,7 triliun untuk masalah sanitasi namun masih dirasa belum 
cukup untuk menanggulangi masalah tersebut.

Sebagai pertimbangan bahwa pada tahun 2025 diperkirakan jumlah pepnduduk di Indonesia mencapai 321 juta jiwa. Tentu saja kebutuhan akan air bersih meningkat tajam. Maka dari itu perlu secepatnya dipersiapkan baik sarana maupun prasarana untuk pemenuhan kebutuhan air bersih. Untuk skala wilayah kecil, pemerintah memiliki program submersible pump yang telah di implementasikan di beberapa kelurahan khususnya di kota Bandung. Keberadaan submersible pump dapat dikatakan sebagai salah satu solusi alternatif pemenuhan kebutuhan air bersih di daerah padat penduduk. Berdasarkan survey awal, warga merasa cukup puas dengan adanya program pemerintah tersebut. Akses akan air bersih mudah di dapat dan kualitas sanitasi meningkat dibanding sebelumnya. Walau pun demikian masih perlu ditingkatkan dalam beberapa aspek diantanya aspek pelayanan yang meliputi ketersediaan, distribusi, dan kualitas air tersebut.

\section{KESIMPULAN DAN REKOMENDASI}

Air memiliki arti penting bagi kesehatan manusia. Kesehatan masnusia dipengaruhi oleh asupan air yang diminum dan digunakan dalam kesehariannya. Rendahnya tingkat pelayanan air memiliki dampak langsung terhadap kualitas kesehatan masyarakat yang serta merta menjadi buruk pula. Kualitas kesehatan yang buruk antara lain disebabkan oleh meminum air yang tidak murni dan layak minum sehingga akan berbahaya bagi tubuh dikarenakan tubuh akan melakukan filter sendiri terhadap zat-zat berbahaya yang terdapat dalam air dan dikonsumsi pada masyarakat pada umumnya. Kondisi tersebut menyebabkan masyarakat menjadi banyak yang mengalami sakit dengan kondisi sakit tersebut akan menurunkan kualitas hidup yang pada akhirnya memperparah kondisi kemiskinan yang sudah dialami. Pentingnya sistem layanan distribusi air bersih setidaknya mampu memberikan pelayanan pada masyarakat dan peluang pada kemandirian desa, serta peluang terhadap desa wisata. Penelitian ini tidak mengkaji melalui analisis kuantitatif sehingga munculnya distribusi berupa nilai atau pendapat responden, sehingga kajian berikutnya disarankan dibuat kuesioner yang mengkaji lebih dalam terkait sistem distribusi secara kuantitatif.

\section{DAFTAR PUSTAKA}

Adisasmito, W. (2007). Faktor Risiko Diare pada Bayi dan Balita di Indonesia. Jurnal Makara
Kesehatan, 11(1), 1-10.

Amalia, B. I., \& Sugiri, A. (2014). Ketersediaan Air Bersih dan perubahan Iklim: Studi Krisis Air di Kedungkarang Kabupaten demak. Jurnal Teknik PWK, 3(2), 295-302.

Anderson, A. R., Drakopoulou-Dodd, S. L., \& Scott, M. G. (2000). Religion as an environmental influence on enterprise culture - The case of Britain in the 1980s. International Journal of Entrepreneurial Behaviour \& Research, 6(1), 5-20. https://doi.org/10.1108/1355255001032305 0

Cahyadi, A., Ayuningtyas, E. A., \& Prabawa, B. A. (2013). Urgensi Pengelolaan Sanitasi Dalam Upaya Konservasi Sumberdaya Air Di Kawasan Karst Gunungsewu Kabupaten Gunungkidul. Indonesian Journal of Conservation, 2(1), 23-32.

Hijriani, A., Muludi, K., \& Andini, E. A. (2016). Penyajian Hasil Prediksi Pemakaian Air Bersih Pdam Informasi Geofrafis. Jurnal Informatika, 11(2), 37-42.

Kalensun, H., Kawet, L., Halim, F., Teknik, F., Sipil, J. T., Ratulangi, U. S., Pangolombian, K., Umum, H., Belakang, L., Masalah, R., Masalah, B., Penelitian, T., \& Penelitian, M. (2016). Perencanaan Sistem Jaringan Distribusi Air Bersih Di. Jurnal Sipil Statik, 4(2), 105-115.

Karsidi, R. (2007). Pemberdayaan Masyarakat Untuk Usaha Kecil dan Mikro (Pengalaman Empiris di Wilayah Surakarta Jawa Tengah). Jurnal Penyuluhan, 3(2). https://doi.org/10.25015/penyuluhan.v3i2.2 161

Kurnianingrum, D., Utama, I. D., Karim, N. A., \& Ratnapuri, C. I. (2019). Analisa Potensi Untuk Pengembangan Industri Kulit di Gunung Puntang Kabupaten Bandung. Jurnal Ekonomi Manajemen \& Bisnis, 20(2).

Kusumawardani, D. (2011). Valuasi Ekonomi Air Bersih Di Kota Surabaya. Majalah Ekonomi, 3, 216-229.

Makawimbang, A. Feby, L. Tanudjaja, E. M. W. (2017). Perencanaan Sistem Penyediaan Air 
Bersih di Desa Soyowan Kecamatan Ratatotok Kabupaten Minahasa Tenggara. Jurnal Sipil Statik, 5(1), 31-40.

Mananoma, T., Tanudjaja, L., \& Jansen, T. (2016). Desain sistem jaringan dan distribusi air bersih pedesaan ( studi kasus desa warembungan ). Jurnal Sipil Sattik, 4(11), 687-694.

McDonald, P. (2011). It's time for management version 2.0: Six forces redefining the future of modern management. Futures, 43(8), 797-808.

https://doi.org/10.1016/j.futures.2011.05.00 1

Mudrikah, A., Sartika, D., Yuniarti, R., \& Satia, A. B. (2014). Kontribusi Sektor Pariwisata Terhadap Gdp Indonesia Tahun 2004 - 2009. Economics Development Analysis Journal, $3(2)$, 362-371. https://doi.org/10.15294/edaj.v3i2.3844

Novita, M. D., \& Marsono, B. D. (2019). Perencanaan Sistem Distribusi Air Minum Kecamatan Arjasa Kabupaten Jember. Jurnal Teknik ITS, 8(2), D112-D117.

Penelitian, B., Sayuran, T., \& Lembang-bandung, J. T. P. (2006). Faktor-faktor yang Mempengaruhi Kepedulian Konsumen terhadap Say- uran Aman Residu Pestisida ( Kasus pada Buah Tomat di Kota Bandung ). 16(1), 77-86.

Rivai, Y., Masduki, A., \& Marsono, B. D. (2004). Evaluasi sistem distribusi dan rencana peningkatan pelayanan air bersih pdam kota gorontalo. SmartEk, 126-134.

Rizkiana, R., Situmorang, A. B., \& Muljo, H. (2008). Persaingan Usaha Industri Telekomunikasi Seluler Indonesia: Perspektif Hukum. Bisnis \& Ekonomi Politik: Quarterly Review of the Indonesian Economy, 9(1), 51-60. https://doi.org/10.1017/CBO978110741532 4.004

Sukartini, N., \& Saleh, S. (2016). Akses Air Bersih di Indonesia. Jurnal Ekonomi Kuantitatif Terapan, 9(2), 228355.
Tusianti, Ema; Prihatiningsih, Dyah Retno; Santosa, D. H. (2019). Analisis Hasil SE2016 Lanjutan POTENSI PENINGKATAN KINERJA USAHA MIKRO $\operatorname{KECIL}$ (A. Said (ed.)). Badan Pusat Statistik.

Wahyudi, S. (2011). Tanggung Jawab Rumah Sakit Terhadap Kerugian Akibat Kelalaian Tenaga Kesehatan Dan Implikasinya. Jurnal Dinamika Hukum, 11(3), 505-521. https://doi.org/10.20884/1.jdh.2011.11.3.17 8

Walangare, K. B. A., Lumenta, A. S. M., Wuwung, J. O., \& Sugiarso, B. A. (2013). Rancang Bangun Alat Konversi Air Laut Menjadi Air Minum Dengan Proses Destilasi Sederhana Menggunakan Pemanas Elektrik. E-Jurnal Teknik Elektrodan Komputer.

Yusuf, M. D., Haryanto, E. V., \& Destari, R. A. (2019). Perancangan sistem pengontrolan distribusi aliran air kerumah berbasis android. Seminar Nasional Sistem Informasi Dan Teknik Informatika, 729-738. 